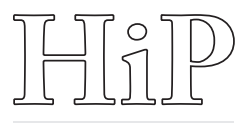

Historia i Polityka

Nr $13(20) / 2015$, ss. $141-157$

ISSN 1899-5160

www.hip.umk.pl

DOI: http://dx.doi.org/10.12775/HiP.2015.009

Mirosław ROMAŃSKI

Uniwersytet Rzeszowski

\title{
Radykalne formy oporu społecznego w Polsce na tle wydarzeń 1968 roku
}

\section{Radical Forms of Social Resistance in Poland in the Context of the 1968 Events}

\begin{abstract}
The fundamental aim of the article is the review of the radicalism manifestation within the social resistance in Poland in the context of the Czechoslovak 1968 events, their range, forms and intensity. The legislative acts and structures eradicating that type of occurrence are described briefly. The Russian intervention in Czechoslovakia in summer 1968, and also the escalation of social resistance in Poland since the beginning of the year, increased the radicalisation of protests. The so-called "Poronin operation” or the act of self-immolation of Ryszard Siwiec during the harvest festival in 1968 were the well known sings of protest of that period.

The article outlines the radical forms of resistance in Poland in 1968 and, at the same time, it is an attempt at a careful reconstruction of the discussed matter. It was written on the basis of the archive records (MSW PRL Ministry of Interior and Administration documentation from Warsaw Institute of National Remembrance), literature, press and other sources.
\end{abstract}

Keywords: social resistance in Poland 1968, radicalism, Czechoslovakia in 1968

Słowa kluczowe: opór społeczny w Polsce 1968 r., radykalizm, Czechosłowacja w 1968 r.

\section{Wstęp, geneza, terminologia i źródła}

Rok 1968 stanowi w dziejach najnowszych tak Polski jak i Europy, datę przełomową. „Praska wiosna” w Czechosłowacji ${ }^{1}$, protesty studenckie w Polsce ${ }^{2}$, następnie interwencja wojsk Układu Warszawskiego w sierpniu 1968 r. w Czechosłowacji ${ }^{3}$, i zmiany na szczeblu władz $\mathrm{PRL}^{4}$, pociągnęły za sobą poważne konsekwencje rów-

R. Kwapis, Praska Wiosna, Toruń 2004, s. 22-34, 55-59.

2 Rewolucje 1968, Warszawa 2008, s. 175-189.

${ }^{3}$ Ł. Kamiński, Wokót praskiej wiosny. Polska i Czechostowacja w 1968 roku, Warszawa 2004, s. 44-58.

${ }^{4}$ J. Eisler, Polski rok 1968, Warszawa 2006, s. 10-22. 
nież dla Polski 5 . Od tych wydarzeń rozpoczął się stopniowy demontaż ekipy Gomułki zakończony zmianami na najwyższych szczeblach władz.

Genezy omawianych wydarzeń należy szukać w Czechosłowacji, gdzie od początku stycznia 1968 r. miała miejsce tzw. praska wiosna, jak również w fali ruchów kontestacyjnych, których apogeum przypadło na r. 1968, i było zarazem częścią szerszego ogólnoświatowego zjawiska protestów. Wiązały się z nim obecne w latach sześćdziesiątych XX w. głosy krytyczne wobec władz, związane ze spiętrzającym się kryzysem społeczno-gospodarczym. Pod naciskiem społecznym doprowadziły one do inicjatyw części przedstawicieli władz PRL, mających na celu wprowadzenie przemian społeczno-politycznych, wśród których nadrzędnym zadaniem było zreformowanie socjalizmu w formie niezależnej od ZSRR. Ogromna presja na wprowadzenie zmian niemałej części społeczeństwa Czechosłowacji, zainicjowała kryzys polityczny w Polsce. Jego początek przypadł na manifestacje studentów, m.in. na terenie Warszawy, Gdańska, Krakowa i Poznania, rozbite przez oddziały MO i ZOMO. Społeczny zryw poparty solidaryzowaniem się wielu obywateli Polski z czechosłowackimi, przerwany został brutalnym wkroczeniem wojsk Układu Warszawskiego do Czechosłowacji w ramach operacji „Dunaj” rozpoczętej dnia 20.08.1968 r. Interwencja wojsk zdławiła procesy reformy, wzmacniając tym samym komunistów.

Po siłowym stłumieniu czerwcowych protestów społecznych 1956 r. w Poznaniu, kiedy otwarcie zamanifestowano niezadowolenie wobec władz ${ }^{6}$, w 1968 r. po raz kolejny na dużą skalę wielu Polaków odważnie udowodniło, że skłonni są do organizowania się w opór i manifestowanie niezadowolenia. Wyrazem tego były liczne demonstracje, które miały uświadomić władzom, że wielu obywateli wciąż nie akceptuje "porządku” utrzymywanego przez ZSRR i żąda zmian. Należy pamiętać, że owe protesty przybierały nie tylko formy grupowych manifestacji. Wśród rozmaitych przejawów niezadowolenia społecznego interesującą kwestią były radykalne ich formy.

Użyty w niniejszym tekście termin „radykalne formy oporu” jest jak najbardziej uzasadniony. O ile formy oporu są na ogół przejawem postaw społecznych, czyli uzewnętrznionymi skłonnościami do reagowania w określony sposób, o tyle jest nimi również trwała organizacja wiedzy, przekonań, uczuć, motywów oraz pewnych form zachowania i reakcji . Znaczenie szczególne ma w nich radykalizm, który w ujęciu powyższym oznacza postawę charakteryzującą się krańcowością

Z. Landau, Polska Gomutki, Warszawa 1995, s. 68-73.

${ }^{6}$ E. Makowski, Poznański Czerwiec 1956. Pierwszy bunt społeczeństwa w PRL, Poznań 2006, s. $20-30$.

7 T. Mądrzycki, Psychologiczne prawidtowości kształtowania się postaw, Warszawa 1977, s. 93. 
oraz skrajnością poglądów i metod ich wyrażania. Zatem użyte w artykule „radykalne formy oporu" wiążą się ze stanowczym i bezkompromisowym podejściem do określonych zagadnien' ${ }^{8}$. Wśród nich wymienić należy różne postawy społeczne - od aktów dywersyjno-sabotażowych, pogróżek słownych, pisemnych, telefonicznych, anonimów krytykujących ustrój, instytucje i osoby, napisów w miejscach publicznych, profanacji, rozpowszechniania plakatów i przesyłek zawierających symbolikę antypaństwową, po drastyczne i ostre formy, jak pobicia, ataki na działaczy partii i funkcjonariuszy władz państwowych, przypadki samospaleń, zamachy bombowe, ich próby itd.

Tematyka radykalnych form oporu nie była jak do tej pory przedmiotem szczegółowych badań. Większość powszechnie dostępnych prac na temat wydarzeń 1968 r. w Polsce odwołuje się do powszechnych form oporu jak wiece, manifestacje, demonstracje, akcje ulotkowe'. $\mathrm{Z}$ tego powodu świadomie zostały one wyłączone w niniejszym tekście, a problematyka poruszana w artykule jest pokłosiem szerszych badań prowadzonych przeze mnie od kilku lat ${ }^{10}$.

Podstawą sporządzenia artykułu były głównie źródła archiwalne wytworzone przez Ministerstwo Spraw Wewnętrznych PRL, a w ich ramach informacje pochodzące z Gabinetu Ministra. Korzystając z nich, sięgnięto po meldunki i sprawozdania napływające z komend wojewódzkich MO. Rolę pomocniczą odegrały też wybrane pozycje literatury i prasy, które na ogół nie zawierają dużo informacji odnoszących się do badanego zjawiska. Zatem podstawy wykorzystanej bazy źródłowej koncentrują się na archiwaliach, które pozwoliły na ukazanie interesujących faktów.

\section{Ustawodawstwo i struktury zwalczające radykalne formy oporu}

W ustawodawstwie PRL przewidziano odpowiednie zapisy prawne, które miały zagwarantować walkę władz z omawianym zjawiskiem. Na ich podstawie powołano specjalne struktury zajmujące się wykrywaniem, rozpracowywaniem oraz eliminowaniem różnych form oporu społecznego. Ponieważ w ustawodawstwie PRL ważną pozycję zajmowały akty dywersji i sabotażu, zostały one ujęte już w obowiązującej wówczas konstytucji stalinowskiej z dnia 22.07.1952 r. i jej artykule 77.

${ }^{8}$ W. Kopaliński, Stownik wyrazów obcych i zwrotów obcojezycznych, Warszawa 1990, s. 428.

9 Te działania też mogą mieć - i niejednokrotnie miały - radykalny charakter, np. kiedy dochodziło do potyczek z oddziałami porządkowymi czy walk ulicznych.

${ }^{10}$ M. Romański, Radykalne postawy społeczne w Polsce w latach 1944/45-1990 (wersja robocza pracy w posiadaniu Autora), ss. 408. 
Przestrzegał on przed dokonywaniem sabotaży, jednocześnie nakładając na obywateli obowiązek strzeżenia własności społecznej, pod groźbą, iż „osoby, które dopuszczają się sabotażu, dywersji, szkodnictwa lub innych zamachów na własność społeczną, karane są z całą surowością prawa" ${ }^{11}$. Od początku lat pięćdziesiątych, po próbach zdefiniowania na nowo istniejących już w prawie polskim po zakończeniu II wojny światowej pojęć „dywersji i sabotażu” ${ }^{12}$, próbowano ponownie dostosować je do wymogów prawa. W sprawach, które nie zostały zakwalifikowane jako sabotaże, a polegały na niszczeniu albo uszkadzaniu zakładów i urządzeń w sytuacji, gdy sprawcy nie zdołano udowodnić pobudek politycznych, postępowano dość łagodnie, co nie odpowiadało wymogom prewencji i społecznej szkodliwości czynów. Wymagało to zmiany wytycznych Najwyższego Sądu Wojskowego, co nastąpiło w uchwale Sądu Najwyższego z 14.06 .1962 r. ${ }^{13}$ Zgodnie z tą uchwała, sabotaż mógł być dokonany tylko w zamiarze bezpośrednim i odstąpiono od konieczności udowodnienia politycznych pobudek działania sprawcy, czyli ustalenia iż jego motywacją była wrogość wobec ustroju PRL. Również projekty nowych kodeksów karanych z lat 1963, 1966 i 1968 nie usiłowały na nowo definiować i rozgraniczać pojęć dywersji i sabotażu ${ }^{14}$. Zgodnie z obowiązującym dekretem z dnia 13.06.1946 r. ${ }^{15}$, jako dywersję i sabotaż w latach sześćdziesiątych traktowano:

1. akty dywersji (art. 3, pkt. 1) - polegające na działaniu skierowanym na naruszenie substancji przedmiotów, na przykład przez umyślne uszkodzenie, złamanie, zepsucie, rozbicie, wybuch, podpalenie, albo na fizycznym oddziaływaniu np. poprzez rozmontowanie, usunięcie itp.,

2. akty szkodnictwa (art. 3, pkt. 2 i 3) - polegające na umyślnym pogarszaniu jakości wyrobów, zwalnianiu tempa wytwórczości, budownictwa, obrotu, na umyślnie wadliwym planowaniu, nieracjonalnym wykorzystywaniu maszyn, sprzętu, środków transportu i innych;

3. akty sabotażu (art. 3, pkt. 2) - stanowiące umyślne wstrzymywanie się sprawcy od wykonania obowiązków, które polegają na opieszałym wykonywaniu w nienależyty sposób ${ }^{16}$.

${ }^{11}$ Dz.U. 1952, nr 33, poz. 232.

12 Projekt kodeksu karnego Polskiej Rzeczypospolitej Ludowej: przepisy wprowadzajace art. 104 i 105, Warszawa 1956, s. 20, 30.

${ }_{13}$ Archiwum Instytutu Pamięci Narodowej (dalej: AIPN), Ministerstwo Spraw Wewnętrznych (dalej: MSW), sygn. 001708/3187, k. 36.

${ }_{14}$ L. Rola, Zbrodnie sabotażu popetnione na terenie Polski $w$ latach 1982-1986, Legionowo 1987, s. 7.

${ }^{15}$ Dz. U. 1946, nr 30, poz. 192.

${ }^{16}$ Uchwała Zgromadzenia Ogólnego 64/54, [w:] Zbiór Orzeczeń Najwyższego Sądu Wojskowego, Warszawa 1954, s. 31-40. 
Wśród radykalnych postaw społecznych wielość czynów, które określono jako przestępstwa przeciwko państwu polskiemu, nastręczała władzom najwięcej kłopotów. Wszak nie wszystkie zostały precyzyjnie określone w kodeksach karanych obowiązujących w Polsce. W polskim prawie kwestie karania za tego rodzaju czyny regulowały kodeksy oraz rozporządzenia wydawane z udziałem organów bezpieczeństwa. W omawianym okresie skoncentrowane były one w tzw. małym kodeksie karnym obowiązującym w latach 1946-1969. Wśród radykalnych form oporu były zagrożenia widziane przez ówczesne władze, jak bezkompromisowe w swej formie przejawy propagandy wizualnej, wyszydzanie ustroju, profanacje symboli państwowych i miejsc upamiętniających wydarzenia historyczne, niszczenie symboli komunistycznych, anonimy, pobicia działaczy i funkcjonariuszy, a także inne ich przejawy, jak rozbrajanie umundurowanych, ich zabójstwa, zamachy, uprowadzenia, ucieczki z Polski drogą powietrzną lub morską, eksplozje i wybuchy, w końcu działalność terrorystyczno-zbrojna.

Wobec zamachów na działaczy państwowych kary określono surowo. W artykule 1 „małego kodeksu karnego” z 1946 r. napisano, że: „kto dopuszcza się gwałtownego zamachu na posła, urzędnika państwowego lub samorządowego, osobę należącą do sił zbrojnych polskich lub sprzymierzonych, członka związku zawodowego, organizacji politycznej albo społecznej o znaczeniu ogólnopaństwowym, podlega karze więzienia na czas nie krótszy od lat 5 lub więzienia dożywotniego". Dalej napisano, że: ,jeśli z wyżej wymienionego czynu wynikła śmierć lub ciężkie uszkodzenia ciała, albo jeśli sprawca dopuścił się gwałtownego zamachu przy użyciu broni lub w innych okolicznościach szczególnie niebezpiecznych, podlega karze więzienia na czas nie krótszy od lat 10 lub dożywotnio albo karze śmierci”. Krótko mówiąc powyższe zapisy oznaczały, że za napaść na funkcjonariusza i urzędnika państwowego można było otrzymać szeroki wymiar kary, bo od 5 lat po karę śmierci. Przy czym, nawoływanie do tego rodzaju akcji mogło skończyć się karą pozbawienia wolności nie krótszą niż 3 lata ${ }^{17}$.

Artykuły 25 i 26 tego samego kodeksu określiły również kary za profanacje miejsc pamięci narodowej i symboli państwowych. Napisano, że: „kto znieważa, uszkadza lub usuwa wystawione publicznie 1) godło, chorągiew lub inny znak państwowy polski, albo państwa sprzymierzonego; 2) pomnik lub inne dzieło, wzniesione w celu uczczenia lub upamiętnienia zdarzeń lub osób, podlega karze więzienia do lat 5 lub aresztu". Taka sama kara groziła za znieważanie miejsc spoczynku żołnierzy polskich i radzieckich. Kara 5 lat oczywiście mogła zostać podwojona jeśli sprawca działał w okolicznościach szczególnie obciążających. Kolej-

17 Dz. U. 1946, nr 30, poz. 192. 
ne artykuły, tj. 27 i 28 dotyczyły różnych form wyszydzania ustroju Polski oraz nawoływania i organizowania grup o charakterze faszystowskim, które to czyny przewidywały kary więzienia do lat $10^{18}$. Dopiero w 1969 r. w nowym kodeksie karnym znanym jako „kodeks Andriejewa”, rozwinięto wiele określeń dotąd konkretnie niesprecyzowanych lub nienależycie rozwiniętych. Artykuł 126 utrzymał za zamach na życie funkcjonariusza publicznego lub działacza politycznego karę wiezienia nie krótszą niż 10 lat lub karę śmierci. W paragrafie 2 wprowadzono zapis zamachu na zdrowie funkcjonariusza lub działacza politycznego, który określono pozbawieniem wolności na 3 lata. Przy zamachach na osoby publiczne, którym często towarzyszyło rozbrajanie oraz kolekcjonowanie broni i materiałów wybuchowych, w art. 143 określono że: „kto bez wymaganego zezwolenia wyrabia, gromadzi lub przechowuje materiały lub przyrządy wybuchowe albo inne przedmioty mogące sprowadzić niebezpieczeństwo dla życia lub zdrowia ludzkiego albo dla mienia w znacznych rozmiarach, podlega karze pozbawienia wolności od roku do lat 10 ”'19. Osobny artykuł 233 rozdziału XXXII „kodeksu karnego” określił też pobicie i napad na funkcjonariusza publicznego, gdzie przewidziano karę od pół roku do 8 lat więzienia, a w artykule 237 opisano znieważanie organów państwowych, za co z kolei groziła kara do 2 lat pozbawienia wolności ${ }^{20}$.

Jednym z ważniejszych problemów, którym władze komunistyczne poświęcały sporo uwagi, była spotykana w szerokiej formie „propaganda wizualna” określana jako formy oporu przejawiające się w środkach przekazu takich jak druk, mowa, obraz, symbol, i mające wpływać na mobilizowanie obywateli do pożądanych działań ${ }^{21}$. Do omawianych form oporu związanych z taką propagandą ustawodawstwo PRL zaliczyło: „publiczne lżenie, wyszydzanie lub poniżanie narodu polskiego, jej ustroju politycznego i społeczno-gospodarczego, naczelnych organów władzy i administracji państwowej oraz ich przedstawicieli”22. Oznaczało to, że każde czyny od kolportażu ulotek po napisy w miejscach publicznych i inne formy rozpowszechniania haseł antypaństwowych, były karalne. Do kolejnych zaliczono: „publiczne pochwalanie faszyzmu lub jakiejkolwiek jego odmiany, rozpowszechnianie fałszywych wiadomości, jeżeli to może wyrządzić poważną szkodę PRL, publiczne nawoływanie do waśni narodowościowych itp." Prawo karne operujące pojęciami „pismo”, „druk” oraz „inny przedmiot”, obejmowało wszystkie

\footnotetext{
18 Ibidem.

19 Dz. U. 1969, nr 13, poz. 94.

20 Ibidem.

21 Wielka Encyklopedia Powszechna PWN, t. 9, Warszawa 1968, s. 467.

22 Dz. U. 1969, nr 13, poz. 94.
} 
formy „propagandy wizualnej”23. Przy nadmienionych radykalnych formach oporu społecznego nie zapomniano o ustanowieniu przepisów karnych „za organizowanie grup i związków o charakterze antypaństwowym, których celem była działalność destrukcyjna skierowana przeciwko linii partii i rozwoju kraju"24.

W strukturze centralnej komunistycznych organów bezpieczeństwa istniały już po II wojnie światowej specjalistyczne komórki zajmujące się zwalczaniem rozmaitych przejawów oporu społecznego. Kluczową rolę w omawianym okresie odgrywało Ministerstwo Spraw Wewnętrznych utworzone w 1954 r. w miejsce Ministerstwa Bezpieczeństwa Publicznego ${ }^{25}$, i podlegające bezpośrednio Radzie Ministrów ${ }^{26}$. Organami terenowymi MSW były komendy wojewódzkie MO, pod które z kolei podlegały komendy powiatowe, a pod te najniższe hierarchicznie komendy gminne oraz posterunki milicji. W ramach MSW do czołowych komórek zajmujących się ściganiem form oporu społecznego, należał Departament IV oraz współpracujący z nim Departament III. Departament IV składał się z siedmiu wydziałów. Do podstawowych jego zadań należało „rozpoznawanie, przeciwdziałanie i likwidacja dywersyjnej szkodniczej, szpiegowskiej i innej antypaństwowej działalności agentury wywiadów imperialistycznych, wrogiego podziemia i innych wrogich elementów na obiektach przemysłowych, rolnych, handlu, łączności, a przede wszystkim na obiektach mających poważne znaczenie dla gospodarki narodowej". Oba nadmienione departamenty wspomagane były w różnym stopniu przez pozostałe. Główną rolę w Departamencie III odgrywały Wydział II odpowiedzialny za zwalczanie tzw. aktów terroru politycznego i zorganizowanej działalności antypaństwowej, a także Wydział VI, który odpowiadał za ochronę gospodarki narodowej, co polegało głównie na walce z dywersją i sabotażem. Analogicznie w komendach wojewódzkich MO na rzecz Departamentu III MSW pracowały Wydziały III ${ }^{27}$.

23 S. Hoc, Zadania Stużby Bezpieczeństwa w zakresie zwalczania przestępstw wrogiej propagan$d y$, Legionowo 1974, s. 17-20.

24 M. Siewierski, Kodeks Karny i prawo o wykroczeniach, Warszawa 1965, s. 200.

25 Dz. U. 1954, nr 54, poz. 29.

26 W. Frazik, B. Kopka, G. Majchrzak, Dzieje aparatu represji w PRL (1944-1989). Stan badań, Warszawa-Kraków 2004, s. 4-5.

27 AIPN, MSW II, Gabinet Ministra, sygn. 1585/1691, k. 5. 


\section{Zakres i oddziaływanie radykalnych form oporu}

Jak już nadmieniono, 1968 r. stanowił napięty okres w dziejach Polski. Niezadowolenie społeczne przeplatające się z "praską wiosną", protestami studenckimi w Warszawie, a także brutalną interwencją zbrojną wojsk Układu Warszawskiego w Czechosłowacji, przenikało się ze społeczną krytyką władz PRL i Gomułki. Napór społeczny na władze, rozpętana przez Gomułkę „kampania antysyjonistyczna" i napięcie sytuacji społeczno-politycznej, wywołały oprócz demonstracji i oficjalnie organizowanych wieców, specyficzne formy zachowań społecznych w których niemałą rolę odgrywały ich radykalne formy. Protesty te miały formę zarówno zbiorową jak indywidualną.

Wydarzenia 1968 r. wpłynęły na zaktywizowanie się grup podziemnych, których działalność z założenia miała godzić w ustrój państwowy. Jedną z nich była formacja o nazwie „Ruch”, której członkowie - Stefan Niesiołowski i Wojciech Majda - wyrażając swój bunt, weszli na szczyt Rys, po czym zrzucili z niego tablicę upamiętniająca pobyt Lenina $\mathrm{w}$ tym miejscu ${ }^{28}$. Ta sama grupa zaplanowała podpalenie poświęconego Leninowi Muzeum w Poroninie, jednak akcja „Poronin" spaliła na panewce na skutek wykrycia zamiarów członków grupy przez Służbę Bezpieczeństwa. Akt oskarżenia objął ponad 30 osób skazanych i był największym procesem politycznym od czasów Polski podziemnej. W ciągu kilku miesięcy aresztowano ponad 100 osób w Warszawie, Łodzi, Gdańsku, Lublinie, Wrocławiu i Bydgoszczy. Wśród skazanych byli: Andrzej Czuma na 7 lat pozbawienia wolności, Stefan Myszkiewicz-Niesiołowski również na 7, Benedykt Czuma na 6, Marian Gołębiowski na 4,5 roku, Emil Morgiewicz na 4 lata, Wiesław Kęcik na 3,5 roku, Marek Myszkiewicz-Niesiołowski na 3,5 roku, Janusz Krzyżewski na 2 lata, a także Jan Kapuściński również skazany na 2 lata pozbawiania wolności ${ }^{29}$. Uczestnicy „Ruchu” zostali pozbawieni wolności za „przygotowania do obalenia przemocą ustroju PRL, przygotowania do podpalenia budynku Muzeum imienia Lenina w Poroninie, kradzież maszyn biurowych i powielaczy, zniszczenie umieszczonej na Rysach tablicy z wizerunkiem Lenina, umieszczanie w miejscach publicznych obelżywych napisów znieważających ustrój Państwa Polskiego" ${ }^{30}$. W obronie oskarżonych wystosowano do ministra sprawiedliwości tzw. List 17, który podpisali m.in. Jerzy Andrzejewski, Jacek Bocheński, Andrzej Braun, Jerzy Ficowski,

28 A. Dudek, Akcja „Poronin” [w:] Ślady PeeReLu. Ludzie, wydarzenia, mechanizmy, red. A. Dudek, Kraków 2000, s. 127-131.

${ }^{29}$ P. Byszewski, Działania Stużby Bezpieczeństwa wobec organizacji Ruch, Warszawa 2008, s. $5-20$.

${ }^{30}$ E. Morgiewicz, Ruch wobec stabilizacji, Karta 1996, nr 20, s. 3-6. 
Zbigniew Herbert, Anna Kamieńska, Andrzej Kijowski, Tadeusz Konwicki, Igor Newerly, Marek Nowakowski, Agnieszka Osiecka, Jarosław Marek Rymkiewicz i Wiktor Woroszylski. Interwencję podjął także prezes Kongresu Polonii Amerykańskiej Alojzy Mazewski. Z inicjatywy Jana Olszewskiego wystosowano kolejny list, do Rady Państwa. Podpisali go, poza sygnatariuszami „Listu 17”, Maria Ossowska i Marian Falski. Z prośbą o ułaskawienie, popartą przez kard. Stefana Wyszyńskiego i Karola Wojtyłę, zwróciła się matka braci Czumów. W wyniku licznych interwencji skazani opuścili po kilku latach więzienia, do czego przyczyniła się amnestia. Część z nich zaangażowała się później w działalność „Ruchu Obrony Praw Człowieka i Obywatela” Leszka Moczulskiego, oraz innych organizacji opozycyjnych ${ }^{31}$.

Powstały też inne organizacje podziemne które cechowały radykalne postawy wobec władz i systemu politycznego. Przykładem było zatrzymanie grupy osób należących do formacji „Gdańska Młodzieżowa Grupa Wywiadowcza”, której celem były napady oraz zamachy na obiekty wojskowe, funkcjonariuszy milicji i strażników przemysłowych. Dokonywano ich w celu zdobycia broni, amunicji i materiałów wybuchowych. Członkowie GMGW zamierzali również dokonać spektakularnej akcji wysadzenia lub spalenia konsulatu radzieckiego w Gdańsku. Założycielem organizacji był Żyd Jakub Szadaj z Gdańska, który dzięki kontaktom ze swą rodziną w Izraelu otrzymywał paczki oraz środki finansowe. Miały one posłużyć do finansowania organizacji. Oprócz niego, milicji udało się aresztować kilku innych członków grupy, a sprawę skierowano do Wydziału Śledczego KW MO w Gdańsku ${ }^{32}$.

Niezadowolenie społeczne widoczne od wiosny 1968 r. wyzwalało gdzieniegdzie sabotażowe formy oporu. Prowokacją do tego typu zachowań, były nierzadko święta państwowe. Dla przykładu, w dniu 1.05.1968 r. nieopodal Mikołowa w woj. katowickim, przy pomocy materiału wybuchowego wysadzono studzienkę wodociągową, powodując spadek ciśnienia w okolicznych osiedlach i zakładach pracy $^{33}$. Usiłowano zatrzymywać produkcję w zakładach, paraliżowano przy pomocy przecinania kabli węzły komunikacyjne itp. Ogółem we wszystkich dziedzinach gospodarki państwowej, Departament III MSW zarejestrował na przestrzeni 1968 r. ponad 80 przypadków sabotaży ${ }^{34}$. Z reguły nie udawało się $S B$ dotrzeć do sprawców tego typu działań. Tak zakończyło się m.in. dochodzenie w sprawie

31 S. Niesiołowski, Organizacja Ruch, Więź 1990, nr 1, s. 2-3.

32 AIPN, MSW II, Gabinet Ministra, sygn. 1585/971, k. 3-4.

33 Tezy dotyczace ochrony gospodarki narodowej, oprac. Departamentu III MSW, Warszawa 1972, s. 4-12.

${ }^{34}$ AIPN, MSW II, Departament III, sygn. 0394/1, t. 6, k. 9-21. 
uszkodzenia kapilary na odlewni Zakładów Mechanicznych „Ursus” w Warsza$w_{i e}{ }^{35}$. Mimo, że w tym okresie prawdopodobieństwo dokonywanych celowo sabotaży było zasadne z uwagi na czas i okoliczności w jakich miały one miejsce, śledztwa tkwiły w martwym punkcie z uwagi na brak dowodów. Kolejnym przykładem była sprawa prowadzona przez prokuraturę w Warszawie, a dotycząca awarii prasy w Warszawskiej Fabryce Obrabiarek, która została wysłana na wystawę do Moskwy w ramach zaprezentowania osiągnięć polskiej techniki. Na miejscu okazało się, że urządzenie nie działa. Przyczyną awarii było wrzucenie w jego przekładnię zębatą, jeszcze przed wysyłką, ciała obcego które w rezultacie spowodowało jej unieruchomienie. W tym przypadku podejrzliwość władz związana była z wydarzeniami politycznymi, jakie miały miejsce w 1968 r., a także fakt że wystawa odbywała się w Moskwie. Ogółem w tej sprawie przesłuchano około 50 osób, a podejrzenie o antypaństwowe poglądy padające na ślusarza Jerzego Kuleszę nie potwierdziło jednoznacznie, że on był sprawcą incydentu. Mimo, że w fabryce tej w niedługim czasie awarii uległa inna maszyna, śledztwa w obu sprawach z uwagi na brak dowodów, zostały jednak umorzone ${ }^{36}$. Nie udało się również zgromadzić wystarczających dowodów sabotażu dokonanego przez Aleksandra Banię na terenie Zakładów Mechanicznych „Ursus”, a polegającego na uszkodzeniu przewodów lakierniczych ${ }^{37}$. Mimo istniejącego zjawiska sabotaży w 1968 r., tego typu formy oporu nie miały w Polsce sporego rozmiaru, choć dość często SB była informowana o próbach zahamowania produkcji czy paraliżowania komunikacji ${ }^{38}$.

Efektem niezadowolenia z interwencji w Czechosłowacji 1968 r., było wrzucenie petardy do sali konferencyjnej budynku KP PZPR w Kętrzynie, oblanie czerwoną farbą pomnika Ludwika Waryńskiego w Puławach, namalowanie na słupach bram wejściowych cmentarza żołnierzy radzieckich we Wrocławiu i czołgu stojącym na cokole swastyki, oraz założenie na głowę pomnika czerwonoarmisty w Nowym Mieście na Mazowszu blaszanego pojemnika na śmieci. Nietypowy był przypadek Karola Małcużyńskiego, dziennikarza telewizyjnego „Monitora”. Odmówił on prowadzenia tego programu po inwazji na Czechosłowację, stwierdzając, że nigdy nie wystąpi w TV, gdy posunięcia polityczne nie będą zgodne z jego przekonaniami. Podobną postawę przyjął pracownik redakcji zagranicznej Polskiego Radia, zapowiadając sabotowanie poleceń służbowych ${ }^{39}$.

\footnotetext{
35 Ibidem, KW MO w Warszawie, sygn. 01207/8210, k. 2-3, 22-23.

${ }^{36}$ Ibidem, MBP, Departament IV, sygn. 01205/3, t. 1, k. 6-7, 202-206.

37 Ibidem, KW MO w Warszawie, sygn. 0250/27, k. 7, 37-39, 83-85.

${ }^{38}$ Ibidem.

39 Ibidem.
} 
Spektakularną formą protestu, podyktowaną sprzeciwem wobec sytuacji społeczno-politycznej i inwazji wojsk Układu Warszawskiego na Czechosłowację, było podpalenie się Ryszarda Siwca w dniu 8.09.1968 r. Zdarzenie miało miejsce podczas ogólnokrajowych dożynek na Stadionie Dziesięciolecia w Warszawie w obecności kierownictwa partii, dyplomatów i około 100 tys. ludzi. Ryszard Siwiec w przeszłości działał w Armii Krajowej. Po wojnie zrezygnował z pracy w szkolnictwie i nie chciał uczestniczyć w komunistycznej indoktrynacji młodzieży. Przez wiele lat pisał na maszynie i powielał ulotki podpisując je jako "Jan Polak”. Agresja na Czechosłowację z udziałem wojsk PRL przekonała go, że trzeba wstrząsnąć sumieniem rodaków ${ }^{40}$. Przed wyjazdem na dożynki do Warszawy sporządził testament i nagrał na taśmę magnetofonową przesłanie: „Ludzie, w których może jeszcze tkwi iskierka ludzkości, uczuć ludzkich, opamiętajcie się! Usłyszcie mój krzyk, krzyk szarego, zwyczajnego człowieka, syna narodu, który własną i cudzą wolność ukochał ponad wszystko, ponad własne życie, opamiętajcie się! Jeszcze nie jest za późno!”. Zanim oblał się rozpuszczalnikiem, rozrzucił w tłum ulotki z protestacyjnym apelem. Płonąc, krzyczał „Protestuję!” i nie pozwalał gasić płomieni. Zmarł po czterech dniach w Szpitalu Praskim z oparzeniami stanowiącymi 85\% powierzchni ciała. Jego protest został przemilczany przez oficjalne media. Bezpośrednim świadkom SB wmawiała, że Siwiec był niezrównoważony psychicznie, a pierwszą informację o jego proteście nadała polska audycja Radio Wolna Europa dopiero w kwietniu $1969 \mathrm{r}^{41}$

Formą oporu często stosowaną było wysyłanie anonimów do różnych decydentów wysokiego, średniego i niskiego szczebla, zwykłych działaczy partyjnych, funkcjonariuszy milicji, wojskowych itp. Oprócz przechwyconych przez SB jedynie w dniu rozpoczęcia inwazji na Czechosłowację, 12 kart pocztowych adresowanych do instytucji centralnych zawierających wulgarne teksty w sprawie inwazji, jednym z najciekawszych był list sygnowany przez „Komitet Obrony Socjalizmu”, przechwycony przez SB w Łodzi. Został wysłany do Prymasa Polski kard. Stefana Wyszyńskiego i zawierał prośbę o przekazanie znajdującego się w nim kolejnego listu z żądaniem rozkazu wycofania wojsk polskich z Czechosłowacji, ministrowi obrony narodowej. Jego autorzy prosili też Prymasa o rozkolportowanie listu oraz odprawienie mszy za całkowite zwycięstwo bratniego narodu czechosłowackie-

${ }^{40}$ Formę samospalenia wybrał prawdopodobnie pod wpływem mnicha buddyjskiego Thích Quảng Đức, protestującego w 1963 r. przeciwko prześladowaniom w Wietnamie buddyzmu przez rząd fanatycznego katolika, dyktatora Ngo Din Diema.

${ }^{41}$ P. Blažek, Živá pochodeñ na Stadionu Desetiletí. Protest Ryszarda Siwce proti okupaci Československa v roce 1968, Praga 2008, s. 93. 
go $^{42}$. Struktury MO i SB wszystkich szczebli zobowiązano do rozpracowywania antypaństwowej działalności i nadsyłania sprawozdań do MSW. Władze posiadały w swojej ewidencji osoby, których działalność określano jako „wywrotową”. $\mathrm{Na}$ terenie woj. kieleckiego należeli do nich m.in. znani z postawy antypaństwowej Piotr Mikos, Aleksander Rozenfeld i Edmund Majchrowicz. Ten ostatni zorganizował w Kielcach podziemną grupę pod nazwą „Polska Organizacja Wojskowa”, a w latach pięćdziesiątych skazany był już na karę śmierci za napady zbrojne. Wyrok jednak zamieniono na dożywocie a następnie 15 lat więzienia. W woj. koszalińskim, gdzie nie odnotowano bezpośrednio wiele działań radykalnych o podłożu politycznym, w kartotece MO figurował Marian Szulc, który pięciokrotnie wysłał anonimy szkalujące ustrój PRL do sekretarza KW PZPR w Lublinie i Koszalinie, a także do redakcji „Głosu Koszalińskiego”. Za powyższe czyny skazano go na pół roku więzienia. Wśród osób o poglądach antypaństwowych i wyrażających swoją postawę w radykalny sposób, był Eugeniusz Nagaj, który w anonimach krytykował dygnitarzy partyjnych i państwowych. O ile, w katowickim nie stwierdzono przypadków psychicznego terroru wobec pracowników i działaczy państwowych, o tyle w woj. krakowskim zarejestrowano aż 41 osób wyrażających swe protesty w najróżniejszy niekonwencjonalny sposób. Naturalnie liczby te nie przedstawiają pełnego zjawiska, a świadczą tylko o ilości wpisanych w ewidencję obywateli permanentnie sprawiających ówczesnym władzom problemy. Wśród nich na terenie woj. krakowskiego byli: Józef Smoczyński, Maciej Jakubowicz, Adam Kunicki, Jan Szuster, Marek Sobolewski, Andrzej Gawlik, Henryk Ambasz, Stanisław Waltoś, Marek Waldenberg, Józef Bogusz, Henryk Brandys, Maria Susułowska, Jan Kliś, Adam Gwiazda, Danuta Zawadowska. Na terenie woj. łódzkiego władze objęły ewidencją 15 osób, a wśród nich Kazimierza Amurskiego wysyłającego władzom partyjnym anonimy o obraźliwej treści, a także popierający w różny sposób „egzekucje” na komunistach Karol Iżykowski, Wacław Adamski, Albin Janasik, Bolesław Szemaszek i Sławomir Musiał, oraz inne osoby - Zdzisław Sikora, Józef Ostrowiak i Józef Szczęsny od wielu lat organizujący grupy studenckie przeciwstawiające się w różny sposób władzom. Do rekordzistów należał ośmiokrotnie karany Jerzy Bittner, manifestujący oficjalnie antypaństwowe poglądy ${ }^{43}$.

$\mathrm{Na}$ terenie woj. olsztyńskiego w wykazach MO ujęto w ewidencję 22 osoby: Wojciecha Wrońskiego, Bohdana Rowińskiego, Stanisława Rosiaka, Józefa Jarosza, Władysława Flakowskiego, Andrzeja Kończaka, Jana Mikitiuka, Mikoła-

\footnotetext{
42 G. Majchrzak, Nie tylko Siwiec, wSieci 2013, nr 12, s. 43-45.

43 AIPN, MSW, sygn. 01207/8210. k. 25-28.
} 
ja Białasa, Seweryna Kamińskiego, Jana Żurawskiego, Franciszka Jodzisa, Piotra Bugajskiego, Józefa Dawidziuka, Stanisława Erbera, Kleofasa Sznytkę, Huberta Falkowskiego, Jerzego Serowskiego, Jana Kellmanna, Bernarda Freitaga, Helmuta Walendszusa, Stefana Grzymkowskiego i Stanisława Skowrońskiego ${ }^{44}$. W opolskim, gdzie stwierdzono tylko jeden przypadek „terroru” o podłożu politycznym, funkcjonariusze sporządzili raport o niejakim Janie Drobczyku, spawaczu zatrudnionym w cukrowni w Raciborzu, który namawiał swego syna Mieczysława - studenta Politechniki Warszawskiej - aby w czasie starć z milicją studenci wraz z nim używali piasku z solą oraz kwasu solnego, rzucając taką mieszankę w oczy milicjantom. Po przekazaniu listu Wydziałowi Śledczemu w Poznaniu, ten wszczął dochodzenie przeciwko Drobczykowi, który przyznał się do napisania listu. Oprócz tej sprawy, poznańska SB nadmieniała o Walentym Wiśniewskim, który wypowiadał się że „za odpowiednio wysoką opłatą mógłby zabić jednego z najwyższych dostojników PRL”5. W woj. szczecińskim sprawę wywieszenia afiszy nawołujących do fizycznej likwidacji komunistów skojarzono z osobami Jana Żyły i Ryszarda Jasnocha, członkami organizacji podziemnej. Poza tym, KW MO w Szczecinie w czerwcu 1968 r. otrzymała nadany ze Stargardu Szczecińskiego napisany na maszynie anonim, powiadamiający, że „na tajnym posiedzeniu nielegalnej organizacji wydano wyroki śmierci na 6 osób zamieszkałych w Stargardzie spośród których było czterech funkcjonariuszy MO i dwóch pracowników rad narodowych"46.

$\mathrm{Na}$ terenie woj. warszawskiego spośród niepokornych obywateli o radykalnych postawach wymieniono: Bronisława Jasińskiego, Józefa Dębskiego, Zbigniewa Olka, Bolesława Złotkowskiego, Mieczysława Korzębę, Henrykę Tomaszewską, Józefa Grabka, Ryszarda Kacperskiego, Mieczysława Koprowicza, Henryka Bobrowskiego, Grzegorza Korpulińskiego, Jolantę Jarke, Mariana Głuchowskiego, Józefa Kałużyńskiego, Stanisława Prokopczuka, Franciszka Gajowniczka, Jerzego Szewczyka, Wiktora Dmowskiego, Zdzisława Zalewskiego, Jana Langiewicza, Jana Mizikowskiego, Jana Woźnicę i Andrzeja Arasimowicza. Milicyjna lista objęła 23 osoby, z których większość bezpośrednio krytykowała ustrój i stosowała różne formy terroru psychicznego o podłożu politycznym wobec władz. Z kolei na terenie woj. rzeszowskiego lista takich osób była skromniejsza, bo obejmowała 8 pozycji. Wśród obywateli o radykalnych poglądach byli: Adam Prusak, Leon Śliżewski, Józef Spólniewski, Władysław Duczyński, Andrzej Grądalski i Feliks Kisa-

\footnotetext{
44 Ibidem, k. 44-55.

45 Ibidem, k. 56-57.

46 Ibidem.
} 
ła, który zapewniał że „Gomułka będzie wisiał”. W woj. zielonogórskim w statystyce MO znaleźli się: Ludwik Michoń, Adam Kućmierz, Piotr Maślaj i Eugeniusz Trawczyński ${ }^{47}$.

Również w okresie nasilenia kampanii antysyjonistycznej miały miejsce różne formy terroru psychicznego skierowane do przedstawicieli władz państwowych. W 1968 r. SB prowadziła sprawy mające na celu ustalenie autorstwa anonimów, które otrzymał członek Biura Politycznego KC PZPR Piotr Jaroszewicz ${ }^{48}$, a także paszkwilu skierowanego przeciwko Zenonowi Kliszce i działaczom rządowym, na którą to okoliczność wszczęto akcję pod kryptonimem „Prowokator”. Okazało się, że jednym z inspiratorów i autorów anonimu jest członek PZPR Jan Słowiński były pracownik naukowy Uniwersytetu Warszawskiego i SGPiS, który z pracownikami Ministerstwa Spraw Zagranicznych postanowił opracować dokument demaskujący rolę Zenona Kliszki w ukrywaniu istotnych faktów dotyczących frakcji żydowskiej w łonie PZPR. W sprawę ponadto zamieszani byli Marian Markiewicz, Mieczysław Miller, Mirosław Gałczyński, Antoni Stachowicz i Ireneusz Sanecki. Również w Lublinie zatrzymano 39-letniego Józefa Olszaka, pracownika umysłowego Przedsiębiorstwa Transportu Budownictwa, który był autorem anonimów kierowanych do ambasad USA i Francji oraz KC PZPR ${ }^{49}$.

Niezależnie od rozpracowań przez SB obywateli o niepokornej postawie, wydarzenia 1968 r. wywołały na terenie całej Polski lawinę radykalnych protestów. Oprócz krytyki udziału w inwazji na terenie Czechosłowacji jednostek Wojska Polskiego, „wrogich wypowiedzi”, ulotek, rezygnacji z przynależności do PZPR, miejsce miały liczne formy oporu nastawione na działania wizualne. Na wielu odprawach z udziałem komendantów MO stwierdzono, że powszechnym w całej Polsce zjawiskiem są napisy na szosach, zakładach pracy, na ulicach i murach. Pojawiały się one niekiedy w bardzo nietypowych miejscach. Np. na terenie kopalni „Makoszowy” w Zabrzu umieszczono je na wózkach kopalnianych na podszybiu około 300 metrów pod ziemią. Pojawiały się również plakaty, pierwsze z nich SB stwierdziła już 23.08 .1968 r. w warszawskim Aninie o treści „Precz z okupacją radziecką”, oraz w Przybyszowicach w woj. rzeszowskim o treści „Precz z ZSRR”. Nietypowy był przypadek Teresy Stodolniak, pracownicy działu zaopatrzenia PLL „LOT”, która plakat „Niech żyje naród czechosłowacki” wywiesiła w oknie biura w którym pracowała. Wcześniej pisała i kolportowała ulotki zawierające protest przeciwko inwazji na Czechosłowację oraz wykonywała nalepki z wezwaniem

\footnotetext{
47 Ibidem, k. 61-62.

48 Ibidem, sygn. 0364/18, k. 1-10.

49 Ibidem, sygn. 1585/1795, k. 32-36.
} 
do udziału w wiecu pod ambasadą radziecką. Paradoksalnie wpadła z powodu cenzury korespondencji - ze względu na nieprzychylne dla władz PRL komentarze w swoich listach, udowodniono jej antypaństwową działalnośćs ${ }^{50}$ Oprócz niej, udało się SB zidentyfikować niektórych autorów antypaństwowej „propagandy wizualnej" i byli to na ogół ludzie młodzi. Zatrzymani w Solcu Kujawskim Andrzej Gadzinowski i Zenon Zonakowski mieli po 17 lat. Najprawdopodobniej najmłodszym ujętym sprawcą był 13-letni uczeń szkoły podstawowej w Opolu - Bogdan Błaszczak ${ }^{51}$.

W 1969 r. dokonano podsumowania walki z „propagandą wizualną” i anonimami za rok poprzedni. Stwierdzono wówczas, że wśród wykrytych sprawców były osoby sprawujące funkcje kierownicze, pracownicy naukowi, umysłowi, robotnicy, rolnicy, studenci i uczniowie różnych szkół, emeryci i renciści, a także księża. Analiza wykazała, że w 1968 r. „propagandą wizualną” zajmowało się też sporo młodzieży nieletniej, ponieważ jej odsetek spośród ogółu posądzanych o te czyny, stanowił około 75\%. Rozpowszechnianiem różnych anonimów zajmowało się zaś $79 \%$ osób. W tym przypadku grupa obejmowała osoby w przedziale wiekowym od 26 do powyżej 60 lat. Ze sporządzonych przez wydziały III KW MO statystyk wynika, że około $70 \%$ działało z pobudek politycznych, a reszta z innych przyczyn (konflikty, porachunki osobiste, żarty, schorzenia psychiczne itp.). Wśród osób działających z pobudek politycznych i wyrażających tak swoją postawę wobec ustroju PRL, byli ludzie w średnim i starszym wieku, natomiast spośród działających z pozostałych pobudek wyróżniono młodzież $\dot{z}^{52}$.

Istotną wagę dla organów bezpieczeństwa państwa stanowily tzw. akty terroru politycznego, które starano się rozpracowywać z dużą precyzją. Sprawy te przeważnie były traktowane jako jedne z ważniejszych, gdyż stanowiły dla władz spore zagrożenie z uwagi na ich charakter. W okresie wydarzeń 1968 r. ważniejsze sprawy rozpracowania przez SB dotyczyły działań w ramach akcji pod krypt. „Petarda” prowadzonej w przez milicję w Kętrzynie, a dotyczącej wrzucenia petardy do sali konferencyjnej KP MO, sprawy pod krypt. „Znicz” założonej przez tę samą komendę, a dotyczącej podpalenia trybuny w święto państwowe 1 Maja, oraz innych spraw opatrzonych krypt.: „Groźba”, „Anonimy”, „Trzykrotka”, „Ewa”, „Lech”, „Jowisz”, „Zamach”, „Groźny”, „Wyrok”, „Szantażysta”, „Torpedo”33.

\footnotetext{
50 G. Majchrzak, Nie tylko Siwiec..., s .44.

51 Ibidem.

52 AIPN, WSO w Szczytnie, sygn. 1490/51, k. 54-56.

53 Ibidem, MSW II, Gabinet Ministra, sygn. 0811/47, k. 7-8.
} 
Praca SB w kwestii ścigania radykalnych form oporu w zasadzie już od połowy lat sześćdziesiątych ulegała stopniowemu pogorszeniu, gdyż pomyślne doprowadzenie spraw do końca nie zdarzało się często. Nie udało się SB wykryć sprawy o krypt. „Tranzyt” na okoliczność zanieczyszczenia żwirem maźnicy lokomotywy, prowadzonej przez KP MO w Sokółce na Podlasiu. Nie wykryto sprawy opatrzonej krypt. „Taśma” odnośnie do przecięcia pasa transportera w Hucie Miedzi w Legnicy, i sprawy pod krypt. „Zasuwa” związanej ze zniszczeniem przy użyciu materiału wybuchowego studzienki przelotowej rurociągu wodnego w Katowicach. Mimo licznych inwigilacji, sprawy o sabotaż należały do grupy stanowiących największe problemy w dochodzeniu ${ }^{54}$.

Ważniejsze obszary występowania radykalnych form oporu społecznego w 1968 roku

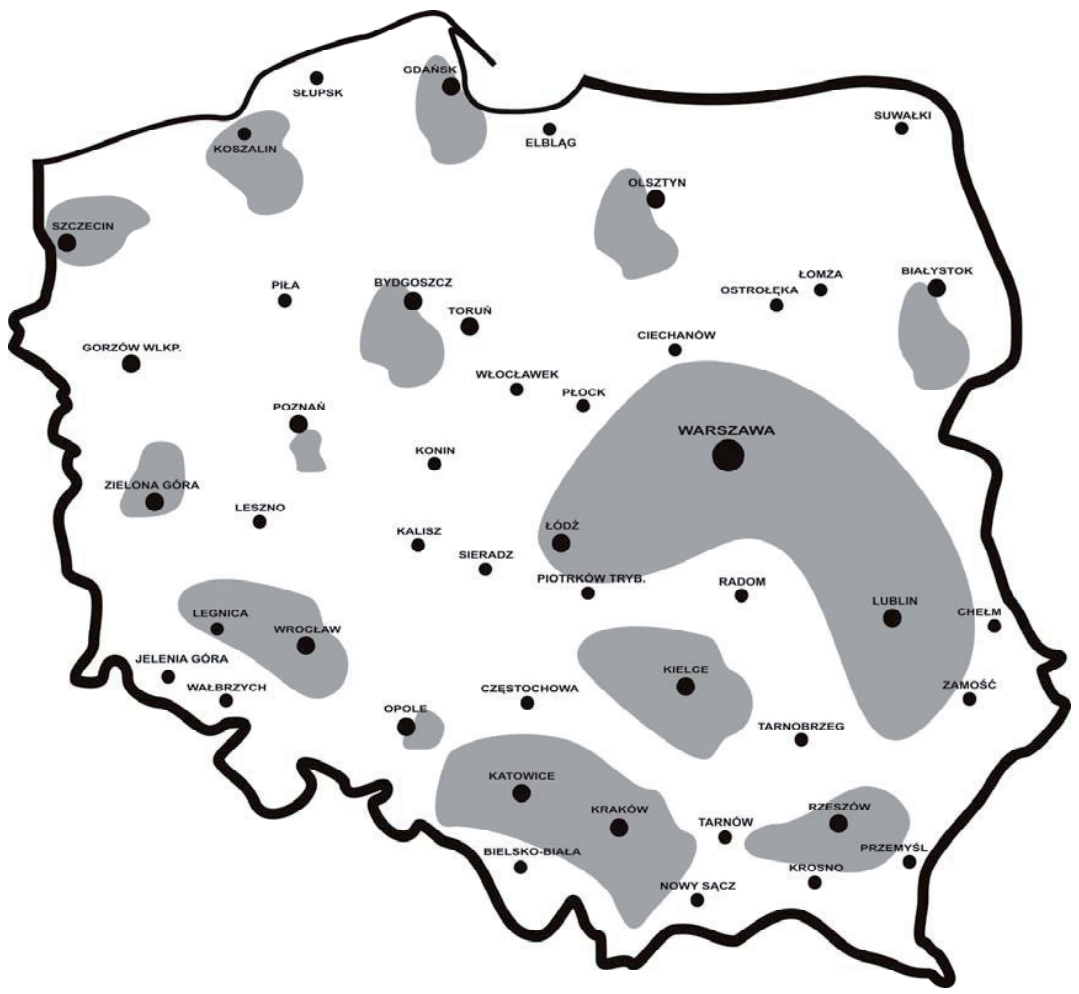

Źródło: opracowanie własne na podstawie materiałów archiwalnych zawartych w przypisach.

${ }^{54}$ Ibidem, k. 9-13. 
Jak wynika z mapy, obszary na których występowały radykalne przejawy oporu społecznego w 1968 r., w większości dotyczyły Polski centralnej, południowej a także Górnego i Dolnego Śląska. W pozostałych województwach nie miały one tak dużego zasiągu, choć niekiedy powtarzały się cyklicznie.

\section{Podsumowanie i wnioski}

W okresie wydarzeń 1968 r. Departament III MSW zarejestrował ogółem około 659 przypadków „propagandy wizualnej”, 353 wysyłania anonimów i listów pogróżkowych do działaczy wszystkich szczebli, 80 sabotaży ${ }^{55}$, 16 kradzieży materiałów wybuchowych celem organizowania różnych spektakularnych akcji wysadzania obiektów, 6 przypadków pobić i napadów na działaczy partyjnych oraz funkcjonariuszy $\mathrm{MO}^{56}$. Grupa radykalnych form oporu była dość spora i mogła obejmować według moich szacunków około 30\% ogółu form oporu społecznego w tym czasie.

Wydarzenia 1968 r. znacznie przyczyniły się w Polce do stopniowego rozkładu ekipy Gomułki. Oliwy do ognia dolały podwyżki zaproponowane przez władze pod koniec 1970 r., co wywołało zamieszki na Wybrzeżu i w rezultacie protesty w wielu miastach Polski. Efektem masakry grudniowej 1970 r. i siłowej pacyfikacji Trójmiasta przez ZOMO, było odwołanie I sekretarza KC PZPR Gomułki i zastąpienie go Edwardem Gierkiem. O ile z początku udało się mu uspokoić nastroje społeczne, o tyle w szybkim czasie okazało się że działania jego ekipy znacznie rozmijały się z oczekiwaniami obywateli.

55 AIPN, MSW II, Departament III, sygn. 0394/1, t. 6, k. 9-21.

56 Ibidem. 